\title{
Developing Students' Research Proposal Design through Group Investigation Method
}

\author{
Selviana Napitupulu ${ }^{1)}$, David Berthony Manalu ${ }^{2)}$ \\ ${ }^{1,2}$ (Teacher Training Faculty of Universitas HKBP Nommensen, Indonesia)
}

\begin{abstract}
This classroom action research was conducted to solve the students' difficulties in designing a research proposal by applying group investigation method. The subjects were the seventh semester students of English Study Program of Teacher Training Faculty of Universitas HKBP Nommensen who took research on ELT course. There were 38 students organized into 8 groups. This research occupied 2 cycles which involved 4 steps (planning, acting, observing, and reflecting) for each cycle. The findings showed that using group investigation method has successfully developed the students' ability in designing research proposal. The development was derived from the increasing of students' mean score in pre-cycle (49.44), first cycle (54.44), and second cycle (66.67). The students' difficulties (i.e. fail to identify qualitative research, decide research title and problems, quote from references, and determine technique of data collection and analysis) decreased significantly after the second cycle had been conducted.
\end{abstract}

Keyword: classroom action research, group investigation method, research proposal design, students' development.

\subsection{Background}

\section{Introduction}

The idea of this project arose from the institutional contextual aim to increase the number of the students to complete their study earlier than the normal time length with a better quality of thesis research reports. This purpose accorded with the promotion of the institution accreditation and reputation quality level. Accordingly, this project assessed a set of quantitative and qualitative data by designing a Classroom Action Research (CAR) to a group of students taking the Research on English Language Teaching (ELT) Course in the English Study Program of Teacher Training Faculty of Universitas HKBP Nommensen in the city of Pematangsiantar, the Province of North Sumatera, Indonesia. The project was conducted in the odd semester of the Academic Year of 2014/2015.

Historically, the time length average needed by the students of the English Study Program of Teacher Training Faculty of Universitas HKBP Nommensen Pematangsiantar to complete their study is eight and a half semesters. This length can be assumed to have a relation to the application of the teaching approach in the delivery of the lessons in the Research Course with the stress on to enable the students to write a research proposal and report. This focus refers to the fact that a thesis is one of the requirements for the completion of the study of a student in the English Study Program of Teacher Training Faculty of Universitas HKBP Nommensen Pematangsiantar.

Facts indicated that Group Investigation Method has a significant effecton students' achievement in learning. Kagan and Kagan (2009: 179) say that by the active role in the task and the natural curiosity of the students, Group Investigation method makes students interactive in small groups of investigators with intrinsic motivation who are able to interpret findings from the information they gather from a variety of sources. This means that this method can be used to develop the ability of the students to write better thesis research proposals and reports that enable them to graduate less than eight semesters from the faculty.

Some previous works indicate that the Group Investigation Method were effective to develop the ability of students in learning. Sharan (1980) reported that Group Investigation Classrooms was found to perform better on high-level questions and those requiring elaboration of responses or the use of problemsolving. In addition to that, Shachar \& Sharan (1995) discovered that Group Investigation Method is directly suited to heterogeneous classrooms and it promoted open verbal interaction and enabled students to become resource persons for other students, highlighting the individual strengths of students from different ethnic groups. Further, Mayasari (2012) investigated the implementation of Group Investigation Method to improve students' writing organization of analytical exposition text. Those facts show that Group Investigation method improves the ability of students in writing and it motivates students in doing works or jobs. 


\subsection{Research Problems}

Based on the researchers' points of view during thesis consultation and examination held by English Study Program of Teacher Training Faculty of Universitas HKBP Nommensen, some of the students were not able to design their research proposal and report because of some points below.

a. Misconception in distinguishing qualitative and quantitative research method.

b. Unintegrated ideas in writing introduction, literature review, and methodology.

c. Providing irrelevant information in the research background.

d. Overusing direct quotation instead of paraphrasing.

In congruent with those facts, the researchers formulated some questions:

- Can Group Investigation method develop students' ability in designing research proposals?

- How does Group Investigation method develop students' ability in designing research proposals?

\subsection{Research Significances}

The findings of this research can contribute important information to refine the status of Group Investigation as an effective Student Centered Activity Teaching Method. It can theoretically provide information on how its stages affect the ability of students to learn better. Practically, the findings can contribute important information on how to make the students interactive in small groups of investigators with intrinsic motivation to interpret findings from the information they gather from a variety of sources.

\section{Literature Review}

A thesis is a collaborative research report which belongs to a student, two consultants and two reviewers. It is one of the requirements for the completion of the program of a student studying in a university. This must be well planned, done and reported project which is initiated in a good proposal which involves the student, his consultants, and his two reviewers. The explanation given by Wilkinson (1991: 96) has a meaning that the introductory part of a research proposal is to provide information which immediately tells the topic and the other research background information which create a place for the birth of research problem embryo to show how it is related to whole parts of a research report. Creswell (2012: 80) says that the review of the related literature is to summarize the relevant information from the written literature, such as journal articles, books, and other documents that describes the past and current state of information on the topic of a research study. Paltridge and Starfield (2007: 119) say that the research method refers to the theoretical paradigm or framework in which a researcher is working; to the stance he or she is taking as a researcher (e.g. choosing a quantitative or qualitative paradigm) and the argument that is built in the text to justify these assumptions, theoretical frameworks and/or approaches as well as the choice of research questions or hypotheses and research method refers to the actual research instruments and materials used

Historically, teaching how to write a thesis research proposal in the research course is by the application of Lecture Teaching Method. It is focused on the supply of knowledge to the demand of the students in order to be able to write a proposal that produces a good research report in the future. On the other hand, Group Investigation teaching method is a new paradigm with a purpose to focus on the activities of the students to develop their beliefs, feelings and attitudes towards the topic at hand and for testing an inquiry through democratic discussions, observations and sharing/listening to others in the group. Thelen (1960: 82) says that the roles are defined and fulfilled through this process by "reading, by personal investigation and by consultation with experts" or sources of information. In 1976, Thelen's model was adapted and developed by Yael and Shlomo Sharan who trained teachers in Group Investigation and researched the outcomes. They conceptualized Group Investigation as a form of advanced cooperative learning, appropriate for students who have become skilled in working together. Investigating in group calls for students to use all the interpersonal and study skills acquired in other cooperative learning methods and to apply them to the planning of specific learning goals. Kagan and Kagan (2009: 17.9) proposed four basic features of Group Investigation, they are: first, by investigation, the classroom becomes a "inquiring community," and each student is an investigator of the class topic or problem; second by interaction, the students interact in small groups throughout the stages of investigation; third by interpretation, students interpret findings from the information they gather from a variety of sources; and fourth by intrinsic motivation, students are intrinsically motivated by their active role in the task and their natural curiosity in the subject matter.

Sharan \& Sharan (1990) proposed the six stages of Group Investigation implementation. Stage 1 is to identify the topic to be investigated and organize students into research groups. Here the teacher presents a broad topic by using questions. She or he stimulates inquiry by having students scan a variety of sources: films, texts, pictures, books, magazines, articles, and so on. She or he organizes students into heterogeneous groups (four or five per group). She or he meets in groups (four or five per group), selects a subtopic, and expresses ideas about what to investigate. Stage 2 is to plan the investigation in group. Here the group members determine 
subtopics for investigation. Groups decide what and how to study. They set the goals of learning. In stage 3, the group members determine subtopics for investigation. Multilateral communication is stressed as students communicate with collaborators, teacher, other groups, and other resource persons. They gather information, analyze and evaluate the data, and reach conclusions. Stage 4, students prepare a report, event or summary. Students organize, abstract, and synthesize information. Groups decide on content and format of their presentation; a steering committee of representatives of the groups coordinates the work of groups. Stage 5, the groups present their final report to the class. Their presentation could be in form of exhibitions, skits, debates, or reports. Stage 6, evaluation (assessment) of higher level learning is emphasized including applications, synthesis, and inferences. Teachers and students may collaborate on evaluation

\subsection{Research Design}

\section{Research Method}

The objective of this project is institutionally to improve the quality of the teaching and learning process of research subject, so it is a classroom action research (CAR) design. Burns (2010: 2) says that an action research involves taking a self-reflective, critical, and systematic approach to exploring teaching contexts. This project follows the four steps of classroom action research model by Kemmis and McTaggart (1988), they are: planning, acting, observing, and reflecting, as in the following diagram.

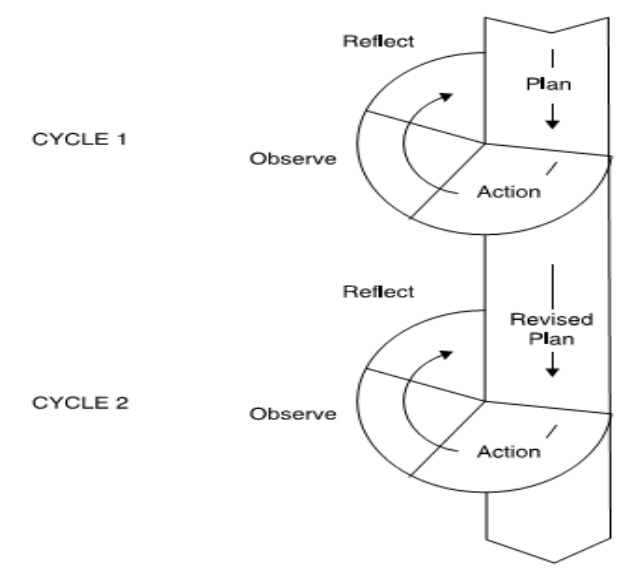

Figure 1. model of CAR cycles by Kemmis and McTaggart(1988)

\subsection{Research Place and Participants}

This research was conducted in English Study Program of Teacher Training Faculty of Universitas HKBP Nommensen. It is located at Jl. Sangnaualuh No.4 in the city of Pematangsiantar, the Province of North Sumatera, Indonesia. The subjects were the seventh semester students (academic year of 2014/2015) who took research on ELT course. There were 38 students and they were grouped into 8 group works. The researchers were the lecturers of this course. This research was held from 19 November 2015 to 17 December 2015 (odd semester) and organized based on the cycles needed in the classroom.

\subsection{Research Procedures}

In Planning Phase, the researchers made some planning based on the finding of preliminary study. The following activities in this action planning were designing lesson plan, preparing the model of group investigation, preparing materials and media, and determining criteria of success.

Designing lesson plan aimed to provide the lecturer with the guideline of teaching and learning activities. The lesson plan included the following items: specific instructional objectives, the instructional materials and media, procedure of presentation, and procedure of assessment.

Next step was preparing the model of group investigation; the use of group investigation in developing students' ability in designing research proposal was applied. The students were designed to work in group cooperatively by four or five students per group. The following step was preparing materials and media. The materials for implementing the action were related to research proposal design. It covered research background, problem, purpose, significances, scope, hypothesis, definition of key terms, literature review, and methodology.

The last step was determining the criteria of success. It was useful for measuring whether the action of this study would be successful or not. In line with the study, the criteria of success were decided based on the agreement between the researcher and the collaborators as follows: the minimum score of research proposal to be accepted was 60 . It was considered developed if $75 \%$ of the students group achieved the same as or above 60 . 
In Acting Phase, the researchers carried out the action based on the lesson plan. In implementing the action, one of the researchers acted as the lecturer who taught research in ELT (English Language Teaching). Another researcher took role as a collaborator to observe all the activities in the teaching learning process. The implementation of the action involved three meetings in each cycle.

In Observing phase, the researchers discussed about the process of recording and gathering all relevant data about any aspect occurred during the implementation of the action. The important aspects in observation were sources of data, the instrument used in collecting the data, and the technique for data collection. In doing the observation phase, the researcher involved in teaching learning activities and the observer observed all the activities in the class. In Reflecting phase, the researchers evaluated teaching-learning process and product to see the development of their research proposals.

\subsection{Data Collection}

Some instruments were applied to obtain the data. The researchers occupied observation dealing with the qualitative data. Field notes were used to evaluate the learning process. On the other side, the researcher used the students' research proposal as a pre-test and post-test to obtain the quantitative data.

\subsection{Scoring Rubric}

To score students' research proposals, the researchers used scoring rubric developed by the English Study Program of Teacher Training Faculty of Universitas HKBP Nommensen.

Table 1. scoring rubric in designing research proposal

\begin{tabular}{|c|c|c|c|c|c|c|c|}
\hline No & Criteria & Description & \multicolumn{5}{|c|}{ Level } \\
\hline 1 & Content and Title & The consistency of title to the problem being discussed & 1 & 2 & 3 & 4 & 5 \\
\hline 2 & The originality of idea & The recency of idea being developed & 1 & 2 & 3 & 4 & 5 \\
\hline 3 & Table of content & The suitability of content to the proposal & 1 & 2 & 3 & 4 & 5 \\
\hline \multirow[t]{4}{*}{4} & \multirow[t]{4}{*}{ Introduction } & The clarity of research background & 1 & 2 & 3 & 4 & 5 \\
\hline & & The clarity of research problem & 1 & 2 & 3 & 4 & 5 \\
\hline & & The clarity of research purpose & 1 & 2 & 3 & 4 & 5 \\
\hline & & The clarity of research significance & 1 & 2 & 3 & 4 & 5 \\
\hline \multirow[t]{4}{*}{5} & \multirow[t]{4}{*}{ Literature Review } & The clarity of literature & 1 & 2 & 3 & 4 & 5 \\
\hline & & The relevance of literature to research problem & 1 & 2 & 3 & 4 & 5 \\
\hline & & The recency of literature used & 1 & 2 & 3 & 4 & 5 \\
\hline & & The consistency of bibliography arrangement & 1 & 2 & 3 & 4 & 5 \\
\hline \multirow[t]{4}{*}{6} & \multirow[t]{4}{*}{ Research Method } & The suitability of method to problem & 1 & 2 & 3 & 4 & 5 \\
\hline & & The clarity of research design & 1 & 2 & 3 & 4 & 5 \\
\hline & & The clarity of collecting data technique & 1 & 2 & 3 & 4 & 5 \\
\hline & & The clarity of data analysis technique & 1 & 2 & 3 & 4 & 5 \\
\hline 7 & Bibliography & The accuracy and consistency in writing references & 1 & 2 & 3 & 4 & 5 \\
\hline \multirow[t]{2}{*}{8} & \multirow[t]{2}{*}{ Other Aspects } & The suitability of proposal writing format & 1 & 2 & 3 & 4 & 5 \\
\hline & & The appropriateness of language use & 1 & 2 & 3 & 4 & 5 \\
\hline \multicolumn{2}{|c|}{ TOTAL } & \multicolumn{6}{|l|}{----} \\
\hline \multicolumn{2}{|c|}{ FINAL SCORE } & \multicolumn{6}{|l|}{$($ Total/90) $\times 100=$} \\
\hline
\end{tabular}

Note: (Level 1=very poor, 2=poor, 3=sufficient, 4=good, 5=very good)

Table 2. category of score

\begin{tabular}{|l|l|l|}
\hline No & Interval & Category \\
\hline 1 & $\geq 60,00$ & Passed \\
\hline 2 & $\leq 59,99$ & Not passed \\
\hline
\end{tabular}

\section{Results}

\subsection{Pre-Cycle}

Pre-cycle meeting was held on Thursday, 19 November 2015. The purpose was to find out the preliminary data before treatment. The researchers asked the students to work in group to design qualitative research proposal. Some books were given to the students as references in order to inspire them to learn qualitative research by their own. This preliminary action did not involve any teaching because there had been explanation about designing a research proposal before this research conducted - at the beginning of the semester.

From this pre-cycle, it was found that only 2 groups $(25 \%)$ were able to design qualitative research proposal. The rest (other 6 groups) were still confused in distinguishing quantitative and qualitative research. They were failed because their research proposals were kinds of experimental and correlational studies. 


\subsection{Cycle I}

\subsubsection{Planning}

The researchers designed two lesson plans for this cycle. The first lesson plan objectives were to introduce the material (qualitative research design) to the students and to plan the investigation in group. Slides of PowerPoint and some e-books (in pdf. format) were prepared to be shared to the students as references. The e-books include Introduction to Research in Education by Ary, Jacobs, and Sorensen (2010), Qualitative Inquiry and Research Design: Choosing among Five Approaches by John Creswell (2007), and Doing Action Research in English Language Teaching by Anne Burns (2010). The objectives of second lesson plan were to carry out the investigation, to prepare and present final report.

\subsubsection{Acting}

In this step, the students were taught the design of qualitative research by starting explaining the types of qualitative research in language classroom. Then, the differences of qualitative to quantitative were exposed by elaborating their specific characteristics. After that, design of qualitative research proposal was shown to the students along with five examples.

After presenting the material, the students were asked to create group work consisting of 4 to 5 members. The task was firstly to find some research problems. The researcher suggested them to share their experiences during teaching practice program at school. After sharing, they were instructed to decide which problems they should focus on. By completing this first point, they, then, should do an investigation to complete their research proposal. The investigations suggested to carry out were reading scientific journals and books, discussing matters to be researched, creating imaginary data, and writing final report. The students were asked to complete those tasks in a week.

A week later, the students presented their report in front of class. Because of the limitation of time (100 minutes), there were only 2 groups presenting their report, while the others were as audiences. All the groups' reports were submitted to be assessed later.

\subsubsection{Observing}

The researchers observed the students' discussion process by monitoring the students' activities in this cycle. The students discussed seriously. Some of them were having argumentation in deciding their research topic. They used laptop and Smartphone as learning tools in seeking information. In communicating their ideas, they spoke Indonesian.

After about 60 minutes, the researchers visited the groups. This was done to monitor their work. If they had difficulties, then the researcher helped them by giving information related to their topic of research.

In group presentation process, each member had role. One of them presented the material, and others were responsible to answer the audiences' questions. Before delivering answers, the group presentation asked the audiences more time to discuss. Presenters and audiences would continuously argue unless the audiences felt satisfied with the answers. The process of presentation was done well, but the problem was only 3 of 8 groups got passed in designing qualitative research proposal.

\subsubsection{Reflecting}

After observing and evaluating the groups' proposal, it was found that only $37,5 \%$ of students' group passed the minimum score. It was concluded that the implementation of group investigation method had not given satisfactory result on the improvement of students' research proposal design. The students did not achieve the minimum score. Most of the students were having problems in designing research introduction and research method. These problems would be the main focus in cycle II. The researchers intended to explain more on those points and provide more examples.

\subsection{Cycle 2}

\subsubsection{Planning}

The researchers designed lesson plan for the second cycle. The design was not so different with the first one. It focused more on the students' difficulties in designing research introduction and method. The students were arranged in group to study more on how to write effective background, research problems and purposes, research significances, and research method. Some effective examples were provided to be given to them.

\subsubsection{Acting}

In the first meeting of cycle 2, the focus of the explanation was about research introduction and method. The researchers showed some examples from their own published journals and other researchers. Before showing their mistakes, students were asked to compare their work with the examples and find their mistakes. The researchers gave 1 week to the students to redesign their proposal. 
In the second meeting of cycle 2, the students reported their proposal. They presented their work in front of class. Then, all their proposals were collected to be assessed to see the result of post-test in second cycle.

\subsubsection{Observing}

The researchers did observation during students' discussion and presentation process. Again, they discussed enthusiastically to revise their proposal. Each member of the group investigated their mistakes by comparing their previous proposal with the examples given by the researcher.

Two groups presented their final report in the next meeting. The researchers observed that their presentations run well. The audiences' questions could be answered effectively. Their performances were good in presenting their paper.

\subsubsection{Reflecting}

After assessing the students' post-test in cycle 2, there were 7 groups achieving the minimum score. The percentage who passed the minimum criterion of 60 score was $87,5 \%$. The mean score was 66,67 . The development percentage was $34,85 \%$. This means the students' ability in designing research proposal has been successfully developed.

Table 3. The results of students' research proposal

\begin{tabular}{|l|l|l|l|}
\hline Students' Group & Pre-Cycle & Cycle I & Cycle II \\
\hline G1 & 50,00 & 61,11 & 73,33 \\
\hline G2 & 43,33 & 48,89 & 63,33 \\
\hline G3 & 62,22 & 71,11 & 78,89 \\
\hline G4 & 46,67 & 48,89 & 57,78 \\
\hline G5 & 43,33 & 46,67 & 60,00 \\
\hline G6 & 44,44 & 47,78 & 63,33 \\
\hline G7 & 61,11 & 63,33 & 73,33 \\
\hline G8 & 44,44 & 47,78 & 63,33 \\
\hline Mean & 49,44 & 54,44 & 66,67 \\
\hline Passing Percentage & $25 \%$ & $37,5 \%$ & $87,5 \%$ \\
\hline
\end{tabular}

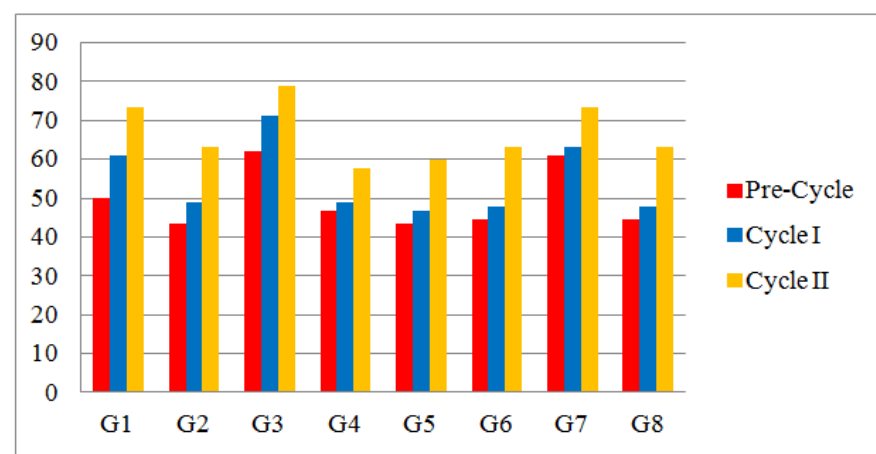

Figure 2. The students' development from pre-cycle to second cycle.

Based on the data analysis, there is better development in students' research proposal. This can be seen from the students' score in the pre-cycle to the second cycle. The mean score for the pre-cycle is 49.44 , while mean score of post-test in cycle 2 is 66.67 . It means that there is 17.23 points or $34.85 \%$ of mean score development. By implementing group investigation, the students' research proposals have been developed successfully. Figure below shows the development of students' research proposal from pre-cycle to cycle 2 .

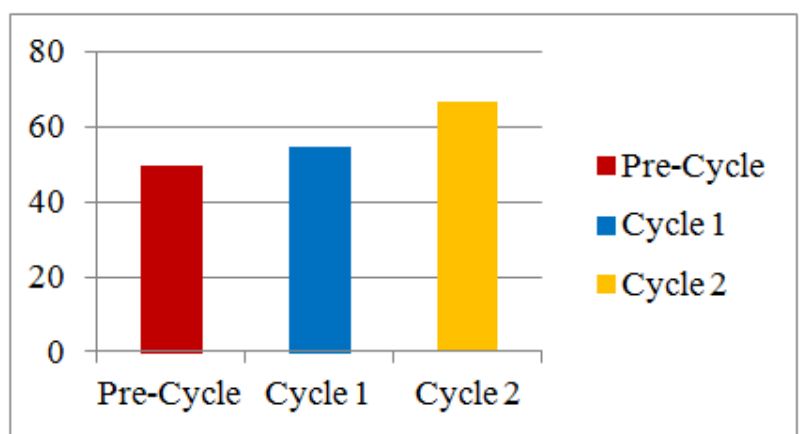

Figure 3. The development of students' research proposal 


\section{Conclusion}

The result of this research indicates that the use of group investigation method has successfully developed the ability of seventh semester students of English Study Program of Teacher Training Faculty of Universitas HKBP Nommensen in designing research proposal.

In the preliminary data, most of the students were not able to differentiate quantitative to qualitative design. The task was to design qualitative research proposal. There were only 2 groups who had designed qualitative research proposals, while others were in quantitative research. After cycle 1, they started to understand the differences of those two research approaches. Their problems in this stage were writing effective research introduction and method. Finally, in cycle 2, most of them were able to differentiate and design qualitative research. There was only one group left behind. This group failure was in designing chapter 3 (i.e. research method). Their technique of data collection and analysis were not suitable to their research problems. Field notes and recorded video during observation show that students were actively and collaboratively engaged in both investigation and presentation process.

Lecturers of Research on ELT Course need to solve students' problems in designing research proposal. The researchers suggest some points of consideration to be focused on while teaching: 1) clear concept of qualitative and quantitative method; 2) the consistency of title to content; 3) quoting relevant theories; and 4) using relevant procedures of data collection and analysis.

The researchers also give suggestion to further researchers to investigate not only in scope of research proposal but the complete research report. There are still many methods of student-centered learning approach which can be applied in teaching and learning process. This research can be used as reference since it is proved that group investigation can develop students' ability in designing research proposal.

\section{References}

[1] S. Kagan, and M. Kagan, Kagan cooperative learning (California: Kagan Publishing, 2009)

[2] S. Sharan, Cooperative learning in small groups: Recent methods and effects on achievement, attitudes, and ethnic relations, Review of Educational Research, 50, 1980, 241-272.

[3] H. Shachar, and S. Sharan, Cooperative learning in the heterogeneous Israeli classroom, International Journal of Educational Research, 23(3), 1995, 283-292.

[4] R. Mayasari, The use of group investigation to improve students' ability in writing skill on analytical exposition Text. Encounter, 3(2), 2012, 137-154.

[5] A. M. Wilkinson, The scientist's handbook for writing papers and dissertations (Englewood Cliffs, NJ: Prenctice Hall, 1991).

[6] J. W. Creswell, Educational research: planning, conducting, and evaluating quantitative and qualitative research (Boston: Pearson, 2012).

[7] B. Paltridge, and S. Starfield, Thesis and dissertation writing in a second language: A handbook for supervisors (New York: Routledge, 2007).

[8] H. Thelen, Education and the human quest (New York: Harper and Row, 1960).

[9] Y. Sharan, and S. Sharan, Group investigation expands cooperative learning, Educational Leadership, 47(4), $1990,17-21$.

[10] A. Burns, Doing action research in English language teaching: A guide for practitioners (New York: Routledge, 2010).

[11] S. Kemmis, and R. McTaggart, The action research planner (Geelong, Australia: Deakin University Press, 1988). 